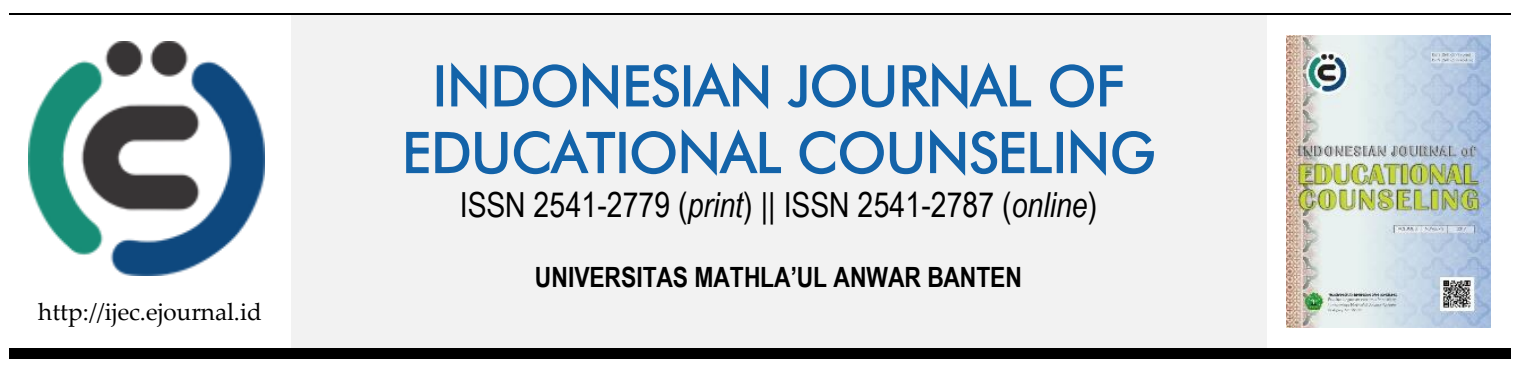

Research Based Article

\title{
Peningkatan Perilaku Prososial Siswa melalui Konseling Teman Sebaya Berbasis Kecakapan Hidup
}

\begin{tabular}{|c|c|}
\hline & $\begin{array}{l}\text { Thrisia Febrianti }{ }^{1}, \text { Mulawarman }{ }^{2} \\
\text { versitas Islam As-Syafi'iyah, }{ }^{2} \text { Universitas Negeri Semarang }\end{array}$ \\
\hline Article History & ABSTRACT \\
\hline $\begin{array}{l}\text { Received: } 25.03 .2019 \\
\text { Received in revised form: } \\
01.04 .2019 \\
\text { Accepted: } 10.04 .2019 \\
\text { Available online: } 05.08 .2019\end{array}$ & $\begin{array}{l}\text { IMPROVING PROSOCIAL BEHAVIOR OF STUDENTS THROUGH PEER } \\
\text { COUNSELING BASED ON LIFE SKILLS. This study aims to improve students' } \\
\text { prosocial behavior through life skills-based peer counseling. The research } \\
\text { method was used experimentally, the design of the pretest-posttest control } \\
\text { group involving one counselor as a peer counseling program supervisor, five } \\
\text { students as peer counselors, and ten students as the experimental group and } \\
\text { the control group. The experimental group used base life skills, while the } \\
\text { control group did not use base life skills. The results of this study indicate that } \\
\text { students who receive assistance from life skills-based peer counseling prove to } \\
\text { be more effective than students who get help from conventional peer } \\
\text { counseling. }\end{array}$ \\
\hline
\end{tabular}

KEYWORDS: Life Skills, Peer Counseling, Prosocial Behavior.

$\begin{array}{ll}\text { DOI: } 10.30653 / 001.201933 .113 & \begin{array}{l}\text { This is an open access article distributed under the terms of the Creative Commons } \\ \text { Attribution } 4.0 \text { International License, which permits unrestricted use, distribution, and } \\ \text { reproduction in any medium, provided the original work is properly cited. }\end{array}\end{array}$

() 2019 Thrisia Febrianti, Mulawarman.

\section{PENDAHULUAN}

Perilaku prososial adalah segala bentuk perilaku yang memberikan konsekuensi positif bagi si penerima, baik dalam bentuk materi, fisik, ataupun psikologis tetapi tidak memiliki keuntungan yang jelas bagi pemiliknya (Baron dan Byrne, 2006). Menurut Kidron dan Fleischman (2006) mengungkapkan bahwa perilaku prososial merupakan tindakan sukarela untuk membantu atau menguntungkan individu dan kelompok lain yang mencakup hal-hal seperti berbagi, menghibur, menyelamatkan, dan membantu.

William (dalam Dayaskisni, 2009) membatasi perilaku prososial secara lebih rinci sebagai perilaku yang memiliki potensi untuk mengubah keadaan fisik atau psikologis penerima bantuan dari kurang baik menjadi lebih baik secara material maupun psikologis. Dalam hal ini dapat dikatakan bahwa perilaku prososial bertujuan untuk membantu meningkatkan well being orang lain, dikarenakan seseorang yang melakukan

${ }^{1}$ Corresponding author's address: Universitas Islam As-Syafi' iyah. Jl. Raya Jatiwaringin No.12, Jaticempaka, Kec. Pondokgede, Kota Bekasi, Jawa Barat 17411, Indonesia; Email: thrisiaf@gmail.com 
tindakan prososial turut mensejahterakan dan membahagiakan kehidupan orang atau penerima bantuan.

Menurut Crisp dan Turner (2007) perilaku prososial (prosocial behavior) dapat diklasifikasikan sebagai berikut diantaranya, persahabatan (friendship), kedermawanan, pengorbanan, saling berbagi, perilaku menolong (helping behaviour), dan sikap kooperatif (cooperative attitude). Hasil penelitian Gregory (2009) mengemukakan bahwa perilaku prososial dalam studi keluarga dari 1.160 remaja berusia antara 13 dan 19 tahun menjelaskan bahwa remaja perempuan dilaporkan secara signifikan lebih prososial dibandingkan remaja laki-laki. Penelitian ini memberikan bukti heritabilitas perilaku prososial dan menunjukkan peran genetik perilaku prososial pada remaja. Penelitian ini mengkonfirmasi temuan efek genetik yang melibatkan antara otak dan perilaku. Selain itu terdapat peran penting dari pengaruh lingkungan sosial yang menekankan perlunya peran persahabatan pada pengembangan perilaku prososial remaja.

Twenge (2007) juga menjelaskan bahwa seseorang akan termotivasi untuk mencari teman-teman baru dan meningkatkan perilaku prososialnya. Perilaku prososial seperti membantu dan bekerja sama merupakan sumber penting dari harmoni sosial dan hubungan baik. Temuan ini konsisten pada tujuh percobaan menggunakan empat cara berbeda mengukur perilaku prososial (menyumbangkan uang, waktu secara sukarela, usaha, membantu kecelakaan, dan bekerjasama). Penurunan perilaku prososial tidak dimoderatori oleh sifat diri atau dengan jenis kelamin, dan ditemukan dengan baik untuk membantu secara spontan dan tanggap terhadap permintaan bantuan secara langsung.

Benabou dan Tirole (2006) menjelaskan untuk mendapatkan pemahaman yang lebih baik dari perilaku prososial, kita berusaha untuk "benar-benar masuk ke dalam semua keinginan dan motif yang mempengaruhinya". Tindakan seseorang mencerminkan gabungan variabel motivasi altruistik, kepentingan, dan kepedulian sosial atau citra diri. Selain itu, gabungan variabel ini bervariasi pada setiap individu untuk dapat menyimpulkan nilai-nilai yang benar dari perilakunya (individu menilai dirinya sendiri). Adapun hal krusial dalam mengubah salah satu dari tiga komponen motivasi, misalnya melalui penggunaan insentif ekstrinsik atau lebih besar diberikan kepada tindakan, mengubah makna yang melekat pada perilaku prososial atau antisosial.

Penelitian Cahyono (2016) menunjukkan bahwa hubungan yang signifikan antara variabel persepsi tentang metode service learning dengan variabel perilaku prososial adalah benar-benar ada dan nyata secara positif. Demikian pula hubungan yang signifikan antara variabel konsep diri dengan variabel perilaku prososial adalah juga benar-benar ada dan nyata secara positif. Secara simultan, variabel persepsi tentang metode service learning dan variabel konsep diri juga membuktikan bahwa kedua variabel merupakan pasangan yang relatif tepat dalam menyumbang signifikansi hubungan dengan variabel perilaku prososial.

Mengajarkan perilaku prososial bisa dengan melibatkan seseorang secara langsung, termasuk emosionalnya untuk merasakan kesusahan. Pengajaran dan pembekalan saja tidak cukup, namun harus ada pembiasaan. Dalam proses pembelajaran, penting bagi individu dilibatkan dengan orang lain, harapannya dapat membangun relasi sosial serta mengenal konsep kapan harus berbuat baik. Konsep-konsep yang diterima akan menguatkan sistem nilai yang dipegang individu. 
Fenomena mengenai perilaku prososial yang rendah dan sedang menuntut semakin eksis dan profesionalnya kerja guru BK ataupun konselor sekolah. Peran konselor sekolah menempati posisi strategis yaitu sebagai rekan atau pendamping siswa dalam menyelesaikan masalahnya. Kenyataannya kondisi di sekolah menunjukkan bahwa eksistensi dan kinerja guru BK masih dihadapkan dengan berbagai kendala. Salah satu penangan yang dapat dilakukan adalah dengan melibatkan siswa sebagai tenaga nonprofesional melalui konseling teman sebaya (peer counseling) untuk meningkatkan perilaku prososial siswa.

Menurut Bett, J.C (2013) menerangkan bahwa pemikiran konseling sebaya didasarkan pada asumsi bahwa orang-orang yang memiliki karakteristik dan usia yang sama cenderung mempengaruhi perilaku satu sama lain secara signifikan. Siswa yang berperan sebagai peer counselor memiliki peran yang dapat mempengaruhi siswa lainnya dalam mengembangkan perilaku positif.

Penelitian Bii, Aloka, and Raburu (2016) menjelaskan bahwa ada korelasi positif yang kuat antara konseling sebaya dan penyesuaian perilaku prososial. Penelitian J. M. Osodo et al (2016) menunjukkan bahwa konseling sebaya memiliki peran penting dalam mempromosikan disiplin diantara siswa di sekolah menengah umum. Penelitian ini merekomendasikan bahwa konselor sebaya harus termotivasi untuk tampil maksimal.

Secara empiris, konseling teman sebaya (peer counseling) efektif dalam meningkatkan perilaku prososial. Selain itu, memberikan perubahan pada siswa dalam bidang sosial maupun perilaku kelompok teman sebaya sebagai kekuatan positif terbukti efektif dalam mempengaruhi perkembangan konsep diri remaja. Budaya teman sebaya yang positif dapat memberikan kesempatan kepada remaja untuk menguji keefektifan komunikasi, tingkah laku, persepsi, dan nilai-nilai yang mereka miliki. Budaya teman sebaya yang positif sangat membantu siswa untuk memahami bahwa ia tidak sendirian dalam menghadapi berbagai tantangan salah satunya mengenai masalah sosial (Aihie dan Egbochuku, 2009).

Beberapa penelitian tersebut menjelaskan keefektifan konseling teman sebaya (peer counseling) untuk membantu siswa dengan berbagai kondisi. Pelaksanaan konseling teman sebaya (peer counseling) yang berbasis life skills memungkinkan konseling dilaksanakan dengan jelas dan terarah. Sebab dengan berbasis life skills, nilai-nilai kecakapan hidup akan mewarnai konseling teman sebaya (peer counseling). Tidak hanya itu, konseling teman sebaya (peer counseling) juga akan memahami peran kecakapan personal dan sosial dalam membantu perilaku prososial. Selain perubahan yang diharapkan, pendekatan ini juga akan menekankan perubahan perilaku. Hal ini menjadi landasan bagi peneliti untuk melakukan konseling teman sebaya (peer counseling) berbasis life skills untuk meningkatkan perilaku prososial siswa.

\section{METODE}

Penelitian ini menggunakan pretest-posttest control group design dengan melibatkan dua kelompok yaitu kelompok eksperimen dan kelompok kontrol. Pada kelompok eksperimen, diberikan konseling teman sebaya (peer counseling) berbasis life skills dan kelompok kontrol diberikan konseling teman sebaya (peer counseling) konvensional. 
Partisipan penelitian terdiri dari satu orang guru BK/konselor, 5 orang siswa sebagai konselor teman sebaya (peer counselor) dan 10 siswa kelas XI terdiri dari 5 orang sebagai kelompok eksperimen dan 5 orang sebagai kelompok kontrol pada saat pretest di SMK Ibu Kartini Kota Semarang. Pelatihan konseling teman sebaya (peer counseling) dengan 3 sesi diberikan kepada siswa sebagai konselor teman sebaya (peer counselor) dan selanjutnya konselor teman sebaya (peer counselor) memberikan bantuan (treatment) untuk meningkatkan perilaku prososial siswa pada kelompok eksperimen dan kelompok kontrol selama 2 sesi pertemuan. Selanjutnya diberikan posttest pada kelompok eksperimen dan kelompok kontrol.

Siswa sebagai tenaga non-profesional yaitu sebagai konselor teman sebaya (peer counselor), siswa sebagai konseli, dan guru BK yang bertindak sebagai supervisor. Kualifikasi pembimbing dalam penelitian ini adalah guru BK/Konselor sekolah dengan latar belakang pendidikan S1 Bimbingan dan Konseling. Tahapan penelitian dijelaskan pada Gambar 1.

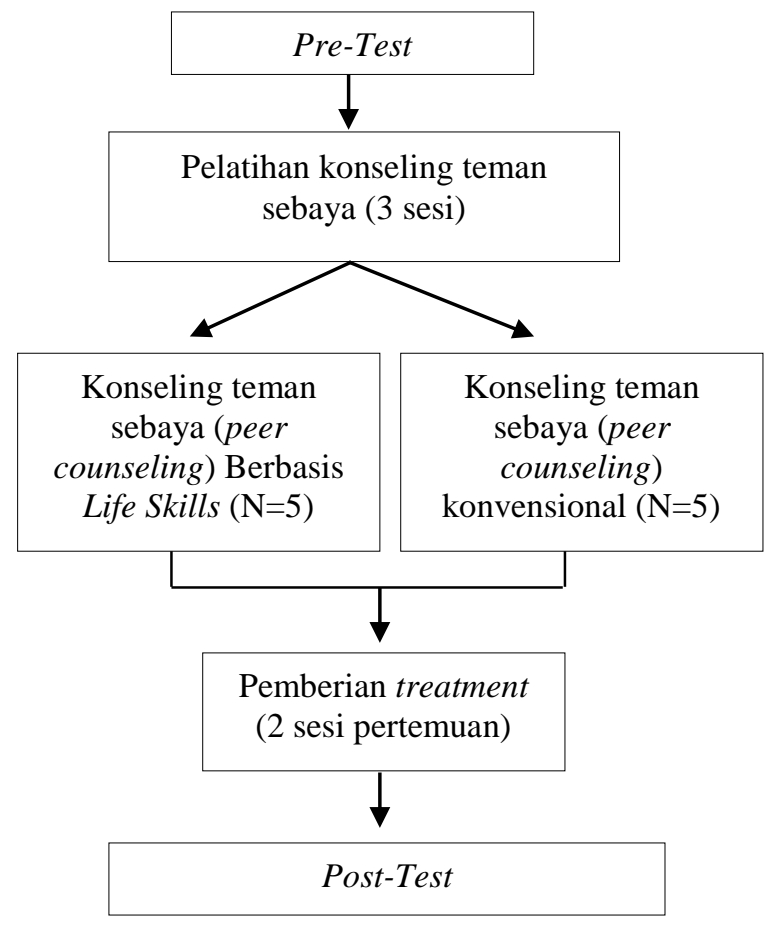

Gambar 1. Tahapan Penelitian

Teknik pengumpulan data yang digunakan dalam penelitian ini adalah menggunakan skala perilaku prososial yang dikembangkan oleh peneliti yang terdiri dari 46 item dengan 5 aspek yaitu menyadari adanya situasi darurat, menginterpretasikan keadaan sebagai situasi darurat, mengasumsikan bahwa tanggung-jawabnya adalah menolong, mengetahui apa yang harus dilakukan, mengambil keputusan terakhir untuk menolong. Pada skala tersebut, peneliti melakukan uji validasi ahli dan kemudian uji coba instrumen. Hasil uji instrumen, semua item dinyatakan 46 valid (rentang rxy: 0.266-0.592) dengan koefisien alpha sebesar 0.89. Selanjutnya data dianalisis dengan menggunakan $t$ test. 


\section{HASIL DAN PEMBAHASAN}

Kondisi perilaku prososial siswa SMK Ibu Kartini Kota Semarang pada kelompok eksperimen pada kategori tinggi sebanyak $0 \%(\mathrm{~N}: 0)$, kategori sedang sebanyak $60 \%(\mathrm{~N}$ : 3), dan kategori rendah sebanyak 40\% (N: 2). Sementara pada kelompok kontol pada kategori tinggi sebanyak $0 \%(\mathrm{~N}: 0)$, kategori sedang sebanyak $40 \%(\mathrm{~N}: 2)$, dan rendah sebanyak $60 \%$ (N: 3). Setelah mendapatkan bantuan (treatment) dari siswa sebagai tenaga non-profesional yaitu konselor teman sebaya yang mengkuti konseling teman sebaya (peer counseling) berbasis life skills, kondisi perilaku prososial siswa pada kelompok eksperimen meningkat menjadi pada kategori tinggi sebanyak 40\% (N: 2), kategori sedang sebanyak $60 \%$ (N: 3), dan kategori rendah $0 \%$ (N: 0). Sedangkan pada kelompok kontrol setelah mendapatkan bantuan (treatment) dari siswa sebagai tenaga non-profesional yaitu konselor teman sebaya yang mengkuti konseling teman sebaya (peer counseling) konvensional meningkat menjadi pada kategori tinggi sebanyak $0 \%(\mathrm{~N}: 0)$, kategori sedang $100 \%$ (N: 5) dan kategori rendah 0\% (N: 0).

Selanjutnya dilakukan uji hipotesis menggunak paired sample t-test. Hasil analisis dengan menggunakan paired sample t-test (tabel 1) menunjukkan bahwa tingkat kelompok eksperimen saat pelaksanaan pre test $(\mathrm{M}=104, \mathrm{SD}=20.29)$ lebih tinggi secara signifikan dibandingkan pada saat post test $(\mathrm{M}=121.80, \mathrm{SD}=17.88 ; \mathrm{t}(4)=-8.64, \mathrm{p}<0.05)$. Selanjutnya tingkat kelompok kontrol saat pelaksanaan pretest $(\mathrm{M}=102.60, \mathrm{SD}=19.19)$ dibandingkan pada saat pelaksanaan postest $(\mathrm{M}=112.80, \mathrm{SD}=16.70 ; \mathrm{t}(4)=-7.32, \mathrm{p}<0.05)$. Hal ini membuktikan dari nilai thitung yang lebih besar dari pada $t$ tabel, dan berdasarkan nilai signifikansi yang bernilai lebih besar atau sama dengan 0.05 .

Selanjutnya, tingkat keefektifan dari kedua kelompok diperoleh dari hasil Gain Score tingkat keefektifan kelompok eksperimen ( $\mathrm{M}$ gain score $=17.80, \mathrm{SD}=4.60)$ dibandingkan dengan kelompok kontrol (M gain score $=10.20, \mathrm{SD}=3.11$ ) Meskipun kedua kelompok dinyatakan efektif namun keduanya memiliki tingkat keefektifan yang berbeda, $\mathrm{t}(8)=$ $3.05, \mathrm{p}<0.05$. Sehingga dapat disimpulkan bahwa konseling teman sebaya (peer counseling) berbasis life skills lebih efektif dibandingkan dengan konseling teman sebaya (peer counseling) konvensional.

Tabel 1. Paired Table Statistics

\begin{tabular}{|c|c|c|c|c|c|c|c|c|c|c|c|}
\hline \multirow{2}{*}{ Kelompok } & \multirow{2}{*}{$\mathrm{N}$} & \multicolumn{2}{|c|}{ Pre Test } & \multicolumn{4}{|c|}{ Post Test } & \multirow{2}{*}{$\mathrm{t}(4)$} & \multicolumn{2}{|c|}{ Gain Score } & \multirow{2}{*}{$t(8)$} \\
\hline & & $\mathrm{K}$ & $\mathrm{M}$ & SD & $\mathrm{K}$ & $\mathrm{M}$ & SD & & $\mathrm{M}$ & SD & \\
\hline Eksperimen & 5 & $S$ & 104 & 20.29 & $S$ & 121.80 & 17.88 & $-8.64^{* *}$ & 17.80 & 4.60 & \multirow{2}{*}{$-3.05^{* *}$} \\
\hline Kontrol & 5 & $S$ & 102.60 & 19.19 & $S$ & 112.80 & 16.70 & $-7.32^{* *}$ & 10.20 & 3.11 & \\
\hline
\end{tabular}

Ket. ${ }^{*} \mathrm{p}>0.05:{ }^{* *} \mathrm{p}<0.05 ;{ }^{* * *} \mathrm{p}<0.01 ; \mathrm{K}:$ Kategori; S: Sedang; T: Tinggi.

Keefektifan konseling teman sebaya (peer counseling) juga dinyatakan Aihie (2009) bahwa peer counseling memiliki efek positif secara signifikan pada konsep diri remaja. Efek positif tersebut disisi lain tentu lebih mudah bagi konselor sebaya untuk memahami masalah temannya. Dari penelitian ini dan yang dilakukan oleh peneliti, peneliti memperoleh hasil bahwa konselor teman sebaya setelah melaksanakan konseling teman sebaya (peer counseling) memperoleh efek positif memahami masalah temannya. Tidak hanya itu, guru BK/konselor memperoleh cara yang efektif dalam memberikan bantuan 
kepada siswa. Dengan demikian, konselor teman sebaya memiliki kemampuan membantu siswa.

Temuan penelitian Chirese (2013) tentang program peer counseling secara konsisten merekomendasikan pelatihan yang memadai terutama dalam keterampilan dasar menolong dan kecakapan hidup. Sebaliknya siswa juga mendapatkan manfaat yang banyak. Selain terciptanya hubungan yang jauh lebih baik antara sesama teman sebaya, siswa juga mendapatkan keuntungan yang positif bagi dirinya. Penelitian ini membuktikan bahwa perilaku prososial siswa telah meningkat setelah diberikan bantuan oleh konselor teman sebaya setelah menerima konseling teman sebaya (peer counseling) berbasis life skills.

Selain keuntungan tersebut, proses konseling teman sebaya (peer counseling) yang dilaksanakan oleh siswa sebagai konselor teman sebaya memberikan keuntungan dari sisi hubungan. Setidaknya terjadi hubungan yang positif antara siswa sebagai teman sebaya yang bersifat kolaboratif. Selain itu, pelaksanaan layanan konseling teman sebaya (peer counseling) berbasis life skills ini juga memberikan perubahan individu memiliki sifat-sifat positif seperti disiplin, mampu bersosialisasi, nilai akademik yang baik, pembicara dan pendengar yang baik, serta mampu menjaga rahasia (Arudo, 2008).

Penelitian Wardani dan Trisnani (2015) juga menerangkan bahwa konseling teman sebaya dapat meningkatkan perilaku prososial siswa. Hasil penelitian menunjukkan bahwa konseling sebaya efektif untuk meningkatkan perilaku prososial siswa. Hasil penelitian ini dapat dijadikan bahan rujukan bagi guru bimbingan dan konseling dalam penyusunan program konseling sebaya untuk mengembangkan perilaku prososial siswa.

Berdasarkan penjelasan diatas penting bagi konselor untuk menerapkan konseling teman sebaya (peer counseling) yang terbukti efektif dalam membantu siswa meningkatkan perilaku prososialnya, selain itu juga memberikan keuntungan dan berbagai dampak positif bagi guru BK dalam memahami permasalahan siswa. Selain itu, konseling teman sebaya (peer counseling) berbasis life skills juga mampu membantu siswa untuk meningkatkan perilaku prososial siswa dengan mendayagunakan peran siswa lain sebagai konselor teman sebaya.

\section{SIMPULAN}

Penelitian ini dilakukan untuk meningkatkan perilaku prososial siswa kelas XI SMK Ibu Kartini Kota Semarang melalui konseling teman sebaya (peer counseling) berbasis life skills. Hasil penelitan ini menujukkan bahwa konseling teman sebaya (peer counseling) berbasis life skills dapat meningkatkan perilaku prososial siswa secara signifikan. Hal ini didasarkan pada perolehan nilai pre test dan post test pada skala perilaku prososial siswa setelah diberikan bantuan (treatment) oleh konselor teman sebaya setelah mengikuti konseling teman sebaya (peer counseling) berbasis life skills dengan bimbingan guru BK/konselor.

Saran bagi guru BK/konselor perlu memperhatikan dan mengembangkan komponen perilaku prososial seperti empati dan altruism. Saran bagi peneliti selanjutnya diharapkan dapat mengembangkan model konseling teman sebaya (peer counseling) berbasis life skill tidak hanya pada kecakapan personal dan sosial namun juga pada 
kecakapan akademik dan vokasional. Serta peneliti selanjutnya diharapkan mampu melakukan pengembangan model sampai uji coba yang lebih luas.

\section{REFERENSI}

Egbochuku, E. O., \& Aihie, N. O. (2009). Peer group counselling and school influence on adolescents' self-concept. Journal of Instructional Psychology, 36(1), 3-12.

Arudo, T. O. O. (2008). Peer counseling experience among selected Kenyan secondary schools. In KAPC Conference, Safari Park Hotel 2nd to 4th September 2008, Nairobi, Kenya.

Baron, R.A., \& Byrne, D. (2006). Social psychology. New York: McGraw Hill.

Bénabou, R., \& Tirole, J. (2006). Incentives and prosocial behavior. American economic review, 96(5), 1652-1678.

Bett, J. C. (2013). The importance of promoting the value and the role of peer counseling among students in secondary schools. International Journal of Economy, Management and Social Sciences, 2(6), 477-484.

Bii, M. C., Aloka, P. J., \& Raburu, P. A. (2016). Efficacy of peer counselling on emotional adjustment among orphaned learners in Kenyan schools. International Journal of Applied Psychology. 6(3), 70-74

Cahyono, Y. B. (2016). Persepsi Tentang Metode Service Learning, Konsep Diri dan Perilaku Prososial Mahasiswa. Persona: Jurnal Psikologi Indonesia, 5(2), 115-125.

Crisp, R. J. \& Turner, R. N. (2007). Essential social psychology. London: Sage Publications.

Dayakisni, T., \& Hudaniah. (2006). Psikologi sosial. Malang: Universitas Negeri Malang (UMM).

Gregory, A. M., Light-Häusermann, J. H., Rijsdijk, F., \& Eley, T. C. (2009). Behavioral genetic analyses of prosocial behavior in adolescents. Developmental Science, 12(1), $165-174$.

Kidron, Y., \& Fleischman, S. (2006). Promoting adolescents' prosocial behavior. Educational Leadership, 63(7), 90-91.

Aihie, O. N. (2009). Effects of peer group counselling and sex on the self-concept of secondary school adolescents: Implications for counselling. Edo Journal of Counselling, 2(2), 189-198. 
INDONESIAN JOURNAL OF EDUCATIONAL COUNSELING 2019, 3(3), 293-300

Osodo, J. M., Osodo, J., Mito, J. W., Raburu, P., \& Aloka, P. (2016). The role of peer counselors in the promotion of student discipline in Ugunja sub-county, Kenya. Asian Journal of Education and Training, 2(2), 63-69.

Twenge, J. M., Baumeister, R. F., DeWall, C. N., Ciarocco, N. J., \& Bartels, J. M. (2007). Social exclusion decreases prosocial behavior. Journal of Personality and Social Psychology, 92(1), 56-66

Wardani, S. Y., \& Trisnani, R. P. (2015). Konseling sebaya untuk meningkatkan perilaku prososial siswa. Psikopedagogia, 4(2), 87-92. 